\title{
Solution for Beehive Strip Dosage Form
}

National Cancer Institute

\section{Source}

National Cancer Institute. Solution for Beehive Strip Dosage Form. NCI Thesaurus. Code C149901.

Liquid preparation consisting of a solution intended for use in the preparation of a bee-

hive strip by application to an absorbent matrix; the bee-hive strip is usually used immediately after preparation. 